удК 349.2

DOI https://doi.org/10.32837/apdp.v0i90.3210

М. В. Клименко

\title{
ГЕНДЕРНА РІВНІСТЬ У ТРУДОВИХ ПРАВОВІДНОСИНАХ: ПИТАННЯ СЬОГОДЕННЯ
}

Постановка проблеми. На шляху демократичного розвитку Україна прагне до створення громадянського суспільства на гуманітарних засадах. Україна останніми роками значно просунулася у вивченні й осмисленні гендерної проблематики. Як усі цивілізовані держави, вона активно проводить гендерну політику, в основі якої лежать загальновизнані міжнародні норми, зафіксовані, зокрема в Загальній декларації прав людини, Конвенції про політичні права жінок, Конвенції про ліквідацію усіх форм дискримінації щодо жінок та інших документах. Україна поділяє принципи ООН і розуміння гендерної рівності як необхідної умови досягнення сталогорозвиткукраїни, створенняумовдлявсебічногорозвиткулюдськогопотенціалу.

Ухвалення Конституції України створило нові правові гарантії формування громадянського суспільства. Вона закріпила нові засади громадянської організації суспільства та, зокрема, принцип рівності жінки і чоловіка («Стаття 24: Не може бути привілеїв чи обмежень за ознаками раси, кольору шкіри, політичних, релігійних та інших переконань, статі, етнічного та соціального походження, майнового стану, місця проживання, за мовними або іншими ознаками. Рівність прав жінки і чоловіка забезпечується наданням жінкам рівних з чоловіками можливостей у громадсько-політичній і культурній діяльності, у здобутті освіти і професійній підготовці, у праці та винагороді за неї...»). Гарантування Конституцією України принципу рівності прав і свобод громадян перед законом має важливе значення в напрямку забезпечення гендерної рівності у трудових правовідносинах.

Актуальність дослідження. Дослідженням проблем дискримінації у сфері peалізації права на працю займалися такі науковці, як О. Антон, Н. Болотіна, М. Венедиктова, О. Гаврилюк, О. Процевський, В. Пузирний, О. Ярошенко. Але у зв'язку із гостротою і актуальністю на сучасному етапі розвитку та становлення України, проблеми дискримінації у сфері реалізації права на працю набувають великого значення та потребують додаткових досліджень.

Метою статті є дослідження гендерної рівності у трудових правовідносинах в умовах сьогодення, на підставі чого зроблено певні висновки.

Виклад основного матеріалу. Поява антидискримінаційного законодавства у сфері трудових відносин відноситься до другої половини 40-х років, коли держави, які приєдналися до Загальної декларації прав людини [1], відповідно до ст. 23 якої кожна людини має право на працю, на вільний вибір роботи, на справедливі та сприятливі умови праці та на захист від безробіття, почали включати в свої конституції положення, що забороняли дискримінацію. У 60-70-х роках у багатьох країнах почали приймати спеціальні закони, спрямовані на боротьбу із дискримінацією. Сьогодні заборона дискримінації у сфері праці так або інакше закріплена в законодавстві всього цивілізованого світу [2, с. 54].

(C) М. В. Клименко, 2021 
Україна, будучи учасницею багатьох міжнародних правових договорів, що сприяють та встановлюють режим гендерної рівності (Загальна декларація прав людини (1948 р.), Міжнародний пакт про громадські та політичні права (1966р.), Статут Організації Об’єднаних Націй (1945р.), Декларація про ліквідацію дискримінації у відношенні жінок (1967р.), Конвенція про ліквідацію усіх форм дискримінації по відношенню до жінок (1979р.), Конвенція про захист прав людини і основоположних свобод (1950 р.), Пекінська декларація (1995 р.) та ін.) у 2005 р. прийняла профільний Закон «Про забезпечення рівних прав та можливостей жінок і чоловіків» [3], яким визначено основні напрями державної гендерної політики, органи влади, відповідальні за її реалізацію, структурні елементи політики з метою забезпечення паритетного становища жінок і чоловіків в усіх сферах життя. На підставі цього Закону Україна почала системно розбудовувати національний механізм утвердження гендерної рівності.

На виконання законодавства відбувається ухвалення національних, регіональних та галузевих планів дій, зокрема Національний план дій із виконання резолюції Ради Безпеки ООН 1325 «Жінки, мир, безпека» на період до 2020 року. Головною метою документа є підвищення рівня дотримання принципу забезпечення рівних прав та можливостей жінок і чоловіків відповідно до Положень Національного плану дій, що мають бути відтворені у відомчих, регіональних та місцевих планах, програмах діяльності [4]. Державна соціальна програма забезпечення рівних прав та можливостей жінок і чоловіків на період до 2021 року, спрямована на укріплення інституційних механізмів забезпечення гендерної рівності з комплексним підходом до подолання інституційних обмежень у сфері гендерної рівності, зокрема удосконалення нормативно-правової бази; урахування гендерного компонента в програмах економічного та соціального розвитку; удосконалення механізму проведення гендерно-правової експертизи тощо [5].

Україною синхронно з Європейським Парламентом було ратифіковано Угоду про асоціацію з ЄС, відповідно до положень якої перед державою постали амбітні завдання щодо покращення якості людського капіталу та встановлення соціальної справедливості, а також забезпечення гендерної рівності та рівних можливостей для представників обох статей у сферах зайнятості, освіти та навчання, економічної і громадської діяльності та у процесі прийняття рішень.

Важливе значення у цьому напрямку має й забезпечення гендерної рівності у трудових правовідносинах. Питання гендерної рівності у сфері трудових відносин сьогодні є досить актуальним і має включати такі принципи: рівність можливостей і однакове ставлення до чоловіків і жінок у сфері зайнятості; рівну оплату праці рівної цінності; поліпшення балансу між роботою і сім’єю для працівників; рівні підходи для пропозицій у разі зайняття вакантних посад.

Наразі відповідно до підпункту 1 пункту 23 Плану заходів на 2018 рік з реалізації Стратегії подолання бідності, затвердженого розпорядженням Кабінету Міністрів України від 14 лютого 2018 року № 99-р, підпункту 2 пункту 41 Національного плану дій з виконання рекомендацій, викладених у заключних зауваженнях Комітету ООН з ліквідації дискримінації щодо жінок до восьмої періодичної доповіді України про виконання Конвенції про ліквідацію всіх форм дискримі- 
нації щодо жінок на період до 2021 року, затвердженого розпорядженням Кабінету Міністрів України від 05 вересня 2018 року № 634-р, пункту 8 Положення про Міністерство соціальної політики України, затвердженого постановою Кабінету Міністрів України від 17 червня 2015 року № 423 (зі змінами) Міністерством соціальної політики України затверджено Методичні рекомендації щодо внесення до колективних договорів та угод положень, спрямованих на забезпечення рівних прав і можливостей жінок та чоловіків у трудових відносинах від 29 січня 2020 р., № 56. Ці рекомендації розроблено з метою забезпечення єдиного підходу до визначення у колективних договорах та угодах вимог щодо створення умов праці, в яких жінки та чоловіки можуть вести трудову діяльність на рівній основі, забезпечується фактична рівність чоловіків і жінок на робочих місцях, не допускається дискримінація за ознакою статі [6].

Також слід згадати й Концепцію комунікації у сфері гендерної рівності, реалізація якої розрахована на період до 2025 р. від 16 вересня 2020 р., яку було схвалено Кабінетом Міністрів України. Серед шляхів і способів розв'язання проблеми недостатнього рівня впровадження принципу рівних прав і можливостей жінок і чоловіків в усі сфери життєдіяльності суспільства Уряд визначає, зокрема, спростування/трансформації гендерних стереотипів щодо професії, соціальних ролей, типів поведінки тощо із залученням відомих жінок і чоловіків, сприяння збільшенню участі жінок у політичній діяльності та процесах прийняття рішень, у тому числі через інформування про позитивне ставлення суспільства до цього, сприяння збільшенню участі жінок і чоловіків у сферах праці, де вони менш представлені, зокрема шляхом інформаційної підтримки самодостатності вибору кожної людини, участі жінок у процесі прийняття рішень та політичній діяльності, розширення економічних прав та можливостей жінок, усунення гендерного розриву в оплаті праці та дотриманні трудових прав та ін. [7]

Сьогодні в Україні все частішими є прояви дискримінації в трудових та тісно пов'язаних 3 ним відносинах. Наслідками дискримінаційних дій роботодавців є порушення прав працівників, зниження рівня зайнятості окремих їх категорій. Найбільшу небезпеку несуть ті види дискримінації, які деформують основи державного й суспільного устрою, зокрема дискримінація за ознакою статі, раси, національності, релігійної приналежності. Сьогодні у світі набуває поширення гендерний рух, представники та прихильники якого стверджують, що «диференціація праці розвиває у жінок почуття неповноцінності й позбавляє їх рівних можливостей у доступі до джерел існування» [8, с. 104]. На жаль, гендерна дискримінація та гендерна нерівність у світі праці залишаються, причиною тому - стійкі гендерні стереотипи, відсутність рівних можливостей та сильніша вразливість жінок до численних форм дискримінації, котрі спостерігаються здебільшого у доступі до зайнятості, професійному зростанні та оплаті праці.

Практика європейського судочинства також свідчить, що європейська спільнота сьогодні надає перевагу зрівнялівці жінок із чоловіками у сфері праці. Так, наприклад, у рішенні по справі Commission V. French Republic Суд ЄC постановив, що заборона на роботу в нічний час для жінок порушує принцип однакового відношення 3 жінками та чоловіками [9, с. 15]. Ідеї гендерної рівності планується вті- 
лити і в новому ТК України, ст. 2 якого однією із засад правового регулювання трудових та пов'язаних із ними відносин проголошує гендерну рівність. Певні спроби провести зрівнялівку чоловіка та жінки у трудових відносинах прослідковуються й в інших нормах Проекту. Такий висновок стає очевидним, якщо порівняти норми ст. 175 чинного КЗПП [10] та ст. 294 Проекту [11], в яких ідеться про важливу юридичну гарантію - обмеження роботи жінок у нічний час. Відповідно до чинного КЗпП дія відповідної статті поширюється на всі категорії працюючих жінок, у той час як у Проекті дана гарантія істотно знижується, оскільки обмеження полягає лише в обов'язку отримання згоди від жінок, які мають дітей до 14-ти років або дітей-інвалідів, на залучення їх до даного виду робіт. Тобто всі інші категорії працюючих жінок, які не підпадають під дію цієї норми, зможуть залучатися до роботи у нічний час безперешкодно, в тому числі й вагітні жінки.

Вирішуючи питання про нормативне закріплення переваг для жінок у сфері праці порівняно із чоловіками, необхідно виходити з того, що є професії, роботи, умови діяльності, які шкідливі не просто для жіночого організму, а для їх репродуктивної функції, й, відповідно, і для здоров'я майбутніх дітей. Тому вірно зазначає щодо цього В.М. Венедиктова: «Зрівняння жінки з чоловіком у суспільному виробництві зовсім не означає, що жінка повинна виконувати важку "чоловічу» роботу» $[12$, с. 132]. Дану позицію зайняли свого часу й учасники 7-го Європейського Конгресу з трудового права та права соціального забезпечення, що проходив у місті Стокгольм 6 вересня 2002 р., які визнали, що встановлення вимог виконання роботи особою певної статі допустимо в інтересах безпеки самих жінок, що включає обмеження застосування жіночої праці на підземних роботах, нічної праці тощо. Було відмічено як негативний прояв тенденції законодавства тих країн ЄС, які стали на шлях поступового скорочення таких робіт, де забороняється та обмежується застосування праці жінок [13].

Ми цілком поділяємо даний погляд на проблему дискримінації за ознаками статі, у розв'язанні якої, на нашу думку, слід відмежовувати випадки, коли жінок усувають від певних видів робіт або обмежують доступ до них задля збереження їх здоров'я, зменшення ризику захворювань майбутніх дітей, від тих ситуацій, коли можуть ставитися перешкоди або взагалі унеможливлюватись певними способами просування жінок по службі, зменшуватись розмір заробітку, у зв'язку з тим, що працівником є жінка. Подібна позиція знайшла закріплення у Законі Україні «Про забезпечення рівних прав та можливостей жінок і чоловіків», у ст. 6 якого закріплюється, що не вважається дискримінацією за ознакою статті соціальний захист жінок під час вагітності, пологів та грудного вигодовування дитини, а також особливі вимоги щодо охорони праці жінок і чоловіків, пов'язані з охороною їх репродуктивного здоров'я.

Нагальною потребою сьогодення є прийняття правових норм, які б забезпечили розвиток статей як рівних, та гендерних відносин, як рівноправних, оскільки правове становище жінки на рівні суспільства і сім'ї є показником розвинутості політичного, соціального і правового державного устрою. Державна політика дедалі більше повинна орієнтуватися на створення рівних можливостей для жінок і чоловіків, при цьому вона повинна проводитися з урахуванням міжнародних доку- 
ментів, підписаних Україною. Це, зокрема, Загальна декларація прав людини, Міжнародний пакт про громадянські і політичні права, Конвенція про ліквідацію всіх форм дискримінації щодо жінок та ін. Запровадження ефективної політики рівноправності передбачає наявність правової бази забезпечення фактичної рівноправності жінок і чоловіків, механізму захисту від дискримінаційного ставлення до себе як жінками, так і чоловіками. Створення національного механізму забезпечення рівних прав і можливостей жінок і чоловіків, як сукупності засобів реалізації ними своїх прав і можливостей, має відбуватися насамперед через формування гендерного законодавства [14].

Висновки. Підсумовуючи вищенаведене, можна констатувати, що Україна вже перебуває на шляху виправлення гендерного законодавства та впровадження норм, принципів і положень, закріплених у міжнародно-правових актах, пов'язаних із наданням рівних прав і можливостей чоловікам і жінкам у трудових відносинах. Водночас під час розроблення реформи трудового законодавства в Україні (1) не допустити звуження наявних прав і гарантій працівників/иць, врахувати принцип рівних прав та можливостей жінок і чоловіків. Визначити розширення економічних можливостей жінок одним із пріоритетів реформи трудового законодавства; (2) забезпечити правові інструменти, що сприятимуть впровадженню принципу рівної оплати праці рівної цінності; (3) урегулювати законодавче забезпечення безпеки праці з виконання робіт з важкими, шкідливими і небезпечними умовами праці, умовами підвищеного ризику для життя і здоров’я.

\section{Jimepamypa}

1. Загальна декларація прав людини від 10.12.1948 р. Офіційний вісник України. 2008. № 93. Ст. 3103.

2. Ярошенко О. Щодо дискримінації в реалізації права на працю. Право України. 2000. № 7. C. 51-54.

3. Про забезпечення рівних прав та можливостей жінок і чоловіків : Закон України від 08.09.2005 р. № 2866-IV. Відомості Верховної Ради України. 2005. № 52. Ст. 561.

4. Про затвердження Національного плану дій з виконання резолюції Ради Безпеки ООН 1325 «Жінки, мир, безпека» на період до 2020 року : розпорядження Кабінет Міністрів України від 24.02.2016 p. № 113-p. URL: https://zakon.rada.gov.ua/laws/show/113-2016-\% D1\% 80\#Text.

5. Про затвердження Державної соціальної програми забезпечення рівних прав та можливостей жінок і чоловіків на період до 2021 року : постанова Кабінет Міністрів України від 11.04.2018 р. № 273. URL: https://zakon.rada.gov.ua/laws/show/273-2018-\% D0\% BF\#Text.

6. Про затвердження Методичних рекомендацій щодо включення до колективних договорів та угод положень, що забезпечують рівні права та можливості жінок і чоловіків у трудових відносинах : наказ Міністерства соціальної політики України від 29.01.2020 p. № 56. URL: https://www. msp.gov.ua.

7. Про схвалення концепції комунікації у сфері гендерної рівності від 16.09.2020 № 1128-р. : розпорядження Кабінету Міністрів України. URL: https:// www.rada.gov.ua.

8. Никольский В. А. Трудовое право Российской Федерации : учебн.-метод. комплекс. Москва : Изд. центр ЕАОИ. 2008. 404 с.

9. Трудове право ЄС : навч. посіб. Київ : Інститут міжнародних відносин КНУ ім. Т. Шевченка, 2004. $185 \mathrm{c}$.

10. Кодекс Законів про працю України від 10.12.1971 р. Відомості Верховної Ради УРСР. 1971. Дод. до № 50. Ст. 375 .

11. Проект Трудового кодексу України від 24.07.2017 p. №1658. URL: https://w1.c1.rada.gov.ua/ pls/zweb2/webproc4_1?pf3511=53221.

12. Венедиктова В.М. Забезпечення фактичної рівності при реалізації права на працю. Право $і$ безпека. 2004. № 3-2. С. 133-134. 
13. Горбачева Ж. Запрет дискриминации по признаку пола в трудовых отношениях в странах Европейского Союза. Права женщин в России: законодательство и практика. 2002. № 3-4(14). URL: http://www.womnet.ru/prava/2002/nomer_14/5.htm.

14. Правове забезпечення реалізації політики гендерної рівності у системі органів виконавчої влади. URL: https://minjust.gov.ua/m/str_4731.

\section{Анотація}

Клименко М. В. Гендерна рівність у трудових правовідносинах: питання сьогодення. - Стаття.

Стаття присвячена питанням гендерної рівності у трудових правовідносинах в умовах сьогодення, на підставі чого зроблено певні висновки. Питання гендерної рівності у сфері трудових відносин сьогодні є досить актуальним і має включати такі принципи: рівність можливостей і однакове ставлення до чоловіків і жінок у сфері зайнятості; рівну оплату праці рівної цінності; поліпшення балансу між роботою і сім'єю для працівників; рівні підходи для пропозицій у разі зайняття вакантних посад.

Зазначено, що нагальною потребою сьогодення є прийняття правових норм, які б забезпечили розвиток статей як рівних, та гендерних відносин як рівноправних, оскільки правове становище жінки на рівні суспільства і сім’ї є показником розвинутості політичного, соціального і правового державного устрою. Державна політика дедалі більше повинна орієнтуватися на створення рівних можливостей для жінок і чоловіків, при цьому вона повинна проводитися з урахуванням міжнародних документів, підписаних Україною. Констатовано, що Україна вже перебуває на шляху виправлення гендерного законодавства та впровадження норм, принципів і положень, закріплених у міжнародно-правових актах, пов'язаних із наданням рівних прав і можливостей чоловікам і жінкам у трудових відносинах. Наголошено, що під час розроблення реформи трудового законодавства в Україні слід (1) не допустити звуження наявних прав і гарантій працівників/иць, врахувати принцип рівних прав та можливостей жінок і чоловіків. Визначити розширення економічних можливостей жінок одним із пріоритетів реформи трудового законодавства; (2) забезпечити правові інструменти, що сприятимуть впровадженню принципу рівної оплати праці рівної цінності; (3) урегулювати законодавче забезпечення безпеки праці з виконання робіт із важкими, шкідливими і небезпечними умовами праці, умовами підвищеного ризику для життя і здоров'я.

Ключові слова: працівник, роботодавець, трудові відносини, дискримінація, гендерна рівність, національне законодавство, міжнародні документи.

\section{Summary}

Klymenko M. V. Gender equality in labor relations: issues of today. - Article.

The article is devoted to the issues of gender equality in labor relations in the current conditions, on the basis of which certain conclusions have been made. The issue of gender equality in the field of labor relations is quite relevant today and should include the following principles: equal opportunities and equal treatment of men and women in employment; equal pay for work of equal value; improving work-life balance for employees; equal approaches to proposals in case of vacancies.

It is noted that the urgent need today is the adoption of legal norms that would ensure the development of gender as equal and gender relations as equal, as the legal status of women at the level of society and family is an indicator of political, social and legal system. Public policy should increasingly focus on creating equal opportunities for women and men, and it should be conducted taking into account international instruments signed by Ukraine. It was stated that Ukraine is already on the way to correcting gender legislation and implementing the norms, principles and provisions enshrined in international legal acts related to the provision of equal rights and opportunities for men and women in labor relations. It is emphasized that when developing the reform of labor legislation in Ukraine it is necessary (1) not to allow the narrowing of existing rights and guarantees of employees, to take into account the principle of equal rights and opportunities for women and men. Identify the empowerment of women as one of the priorities of labor law reform; (2) to provide legal instruments that will promote the implementation of the principle of equal pay for work of equal value; (3) to regulate the legislative provision of occupational safety for work with difficult, harmful and dangerous working conditions, conditions of increased risk to life and health.

Key words: employee, employer, labor relations, discrimination, gender equality, national legislation, international documents. 